\title{
Effect of arachidonic acid supplementation and cyclooxygenase/ lipoxygenase inhibition on the development of early bovine embryos
}

\author{
Rosa Maria Pereira ${ }^{1 *}$, Carla Cruz Marques ${ }^{1}$, Maria da Conceição Baptista ${ }^{1}$, Maria Irene \\ Vasques ${ }^{1}$, António Eduardo Horta ${ }^{1}$
}

\author{
1 Investigador Auxiliar da Estação Zootécnica Nacional. \\ * Departamento de Reprodução Animal, Estação Zootécnica Nacional - INIAP, 2005-048 Vale de Santarém, Portugal. Fax: 351243767307 ; \\ Telefone: 351243767316.
}

\begin{abstract}
The effect of arachidonic acid (AA) cascade on bovine embryo development in a granulosa cell co-culture system was studied. Arachidonic acid $(100 \mu \mathrm{M})$ was supplemented from 1-cell to 8-16 cell block stage (first three days of coculture) and from 1-cell to hatching. Specific cyclooxygenase (indomethacin, $28 \mu \mathrm{M}$ ) and lipoxygenase (nordihydroguaiaretic acid - NDGA, $28 \mu \mathrm{M}$ ) inhibitors were used from 1-cell to 8-16 cell block stage with AA. Embryo development was assessed by cleavage, day 7-day 8 and hatched embryo rates and by measuring growth rates through development stages found in days 7-10 of culture (day $0=$ insemination day). Embryo quality was scored at day 8 . A $6.5-10.4 \%$ increase on cleavage rate after AA supplementation was found. This AA supplementation from 1-cell to hatching delayed embryo growth rate beyond day 7 and a reduction on hatching rate was detected. When AA supplementation was restricted to the first three days of co-culture those negative effects were overcome. Also, indomethacin and NDGA prevented the positive effect of AA and induced a significant reduction on cleavage, respectively. NDGA further decreased day 7 embryo rate and quality. Results suggest that AA has a two-phase action on bovine embryos, promoting early development and impairing embryo growth from day 7 onwards and hatching rates. Both cyclooxygenase and lipoxygenase were found to be important pathways to promote cleavage.
\end{abstract}

Key Words: arachidonic acid, bovine embryos, granulosa, in vitro

\section{Influência do ácido araquidónico e da inibição da ciclo-oxigenase ou lipo- oxigenase no desenvolvimento inicial de embriões bovinos}

RESUMO - Estudou-se a influência da cascata do ácido araquidónico (AA) no desenvolvimento de embriões bovinos produzidos in vitro em co-cultura com células da granulosa. Os embriões foram suplementados com AA $(100 \mu \mathrm{M})$ desde o estádio de 1 célula até 8-16 células (primeiros três dias de co-cultura) ou até a eclosão. Introduziram-se inibidores específicos da ciclooxigenase (indometacina, $28 \mu \mathrm{M}$ ) e da lipo-oxigenase (ácido nordihidroguaiarético - NDGA, $28 \mu \mathrm{M}$ ), juntamente com o ácido araquidónico, desde o estádio de 1 célula até 8-16 células. O desenvolvimento embrionário foi avaliado pelas taxas de clivagem de embriões nos dias 7 e 8 (D0 = dia da inseminação) e eclodidos. Avaliou-se também a velocidade de crescimento dos embriões entre os dias 7 e 10 de cultura e a qualidade dos embriões no dia 8. A suplementação dos embriões com AA aumentou a taxa de clivagem $(6,5$ e 10,4\%). Por outro lado, a presença deste percursor das prostaglandinas e dos leucotrienos com os embriões desde o estádio de 1 célula até a eclosão atrasou sua velocidade de crescimento a partir do dia 7 e reduziu a taxa de eclosão em $20.4 \%$. Estes efeitos negativos desapareceram quando a suplementação do AA foi restringida apenas aos três primeiros dias de co-cultura. A indometacina evitou o efeito positivo do AA na clivagem, tendo o NDGA reduzido esta taxa, mesmo em presença do AA, assim como a taxa de embriões em D7 e a qualidade dos embriões D8. Os resultados sugerem que o ácido araquidónico tem efeito bifásico nos embriões bovinos, promovendo o início do seu desenvolvimento e, após D7, diminuindo as taxas de crescimento e eclosão. Ambas as vias metabólicas da ciclo-oxigenase e lipo-oxigenase parecem importantes na clivagem.

Palavras-chave: ácido araquidónico, embriões bovinos, granulosa, in vitro

\section{Introduction}

Arachidonic acid (AA) is metabolized by cells into prostaglandins, hydroperoxyeicosatetraenoic acid(HPETE) and derivatives such as leukotrienes, through the action of cyclooxygenases (COX) and lipoxygenases (LOX) (Samuelsson et al., 1979; Robertson, 1995). Prostaglandins, leukotrienes and HPETE derivatives are implicated in a great variety of reproductive processes, such as ovulation (Orczyk \& Behrman, 1972; Reich etal., 1983; Murdoch, 1988), oocyte maturation(Murdoch, 1988; Marques etal., 1997), fertilization(Gurevich etal., 1993; Baptista et al., 2000) and embryo development (Thatcher et al., 1984). 
Cyclooxygenase has been detected as early as two-cell stage of embryonic development (Gurevich \& Shemesh, 1994; Van der Weiden et al., 1996) while prostaglandins have been implicated in a number of embryo physiological processes including blastocyst expansion and hatching (Biggers et al., 1978; Lewis, 1986 and 1989). Although preimplanted bovine embryos are able to produce prostaglandins from 2-cell stage onwards (Lewis et al., 1982; Gurevich \& Shemesh, 1994; Nadeau et al., 1994), neither the expression of LOX enzymes nor the synthesis of LOX pathway metabolites have been identified. Nevertheless, Charpigny et al. (1997) established that ovine embryos could metabolize AA into leukotrienes and hydroxyeicosatetraenoic acids (HETE) during the preimplantation period.

Our first objective was to study the effect of AA supplementation from 1-cell to 8-16 cell block stage as well from 1-cell to hatching on bovine embryo development. Secondly, the role of COX and LOX metabolites on all embryonic developmental stages was studied through inhibition of the pathways from 1-cell to 8-16 cell block stage.

\section{Materials and Methods}

Bovine ovaries were collected at a nearby slaughterhouse and transported to the laboratory within 2.5 hours in thermo flasks containing Dulbecco's phosphated buffered solution (PBS, GibCo, ref. 14040-91). PBS was supplemented with $0.15 \%$ of bovine serum albumine (w/v, BSA, Fraction V, Sigma, ref. A-7888) and $0.05 \mathrm{mg} \mathrm{mL}^{-1}$ of kanamycin (Sigma, ref. K-4000). The thermo flasks were maintained at $37^{\circ} \mathrm{C}$ or $4^{\circ} \mathrm{C}$ before using the ovaries for embryo production or granulosa cell culture, respectively.

Selected unexpanded cumulus-oocyte complexes were aspirated from 2-6 mm follicles and matured in Petri dishes (Sterilin, Denmark) containing $3 \mathrm{~mL}$ of maturation medium consisting of M-199 with Earle's salts, L-glutamine and 25 mM Hepes (GibCo, ref. 22340-020). This medium was supplemented with $10 \%$ of superovulated oestrus cow serum (SOCS), $100 \mathrm{IU} \mathrm{mL}^{-1}$ penicillin and $100 \mathrm{mg} \mathrm{mL}^{-1}$ streptomycin (Sigma, ref. P0781). Maturation was accomplished in an incubator at $39^{\circ} \mathrm{C}$ with humidified atmosphere in air and 5\% CO2 for 22-24 hours according to Gordon(1994).

After maturation, oocytes were partially denuded of surrounding expanded cumulus cells and placed into $40 \mu \mathrm{l}$ drops of fertilization medium (10/drop) consisting of modified Tyrode's medium (TALP) overlaid by paraffin oil (Sigma, ref. $\mathrm{M}-8410)$. TALP was supplemented with $5.4 \mathrm{USP}_{\mathrm{mL}}^{-1}$ of heparin (Sigma, ref. H-3393), $10 \mathrm{mM}$ of penicillamine (Sigma, ref. P-4875), $20 \mathrm{mM}$ of hypotaurine (Sigma, ref. H-1384) and $0.25 \mathrm{mM}$ of epinephrine (Sigma, ref. E-1635). Thawed bovine semen was incubated as described for maturation during 1 hour in TALP without calcium supplemented with $2.4 \mathrm{mM}$ of caffeine (Sigma, ref. C-0750) for swim-up. Selected spermatozoa $\left(1 \times 10^{6} \mathrm{~mL}^{-1}\right)$ and oocytes were incubated altogether for 22 hours at the same conditions as described for oocytes. After co-incubation, presumptive zygotes were transferred to granulosa cell monolayers where embryo coculture proceeded for 12 days.

Granulosa cells $\left(1 \times 10^{6} \mathrm{~mL}^{-1}\right)$ collected from refrigerated ovaries were cultured in $100 \mu 1$ droplets of M199, 10\% SOCS and antibiotics, placed in $60 \mathrm{~mm}$ Petri dishes (Nunc $\AA$, Denmark) and covered with paraffin oil. These cells were cultured for 2-3 days previously to zygotes transfer allowing a confluent monolayer to be formed.

Experimental design

\section{Experiment 1}

Arachidonic acid (100 $\mu \mathrm{M}$, Sigma, ref. A-3555) was added to embryo culture medium to refresh embryos from 1-cell stage to hatching (group AA1: 730 zygotes in 11 replicates). A group without AA supplementation (Control: 715 zygotes in 11 replicates) was also cultured simultaneously.

\section{Experiment 2}

Indomethacin, a specific inhibitor for $\mathrm{COX}$ and nordihydroguaiaretic acid (NDGA) a specific inhibitor for LOX (Salari et al., 1984), were used in this experiment. The following treatments were administered only for three days starting at the moment of zygotes transfer to the monolayers.

Group AA2 (642 zygotes in 11 replicates): arachidonic acid (100 $\mu \mathrm{M}$, Sigma, ref. A-3555) was added to embryo culture medium;

Group INDO (658 zygotes in 11 replicates): same as group AA2 plus Indomethacin ( $28 \mu \mathrm{M}$, Sigma, ref. I-7378);

Group NDGA (648 zygotes in 11 replicates): same as group AA2 plus NDGA ( $28 \mu \mathrm{M}$, Sigma, ref. N-5025); and

Control group (646 zygotes in 11 replicates): with no AA supplementation.

Experiments 1 and 2 were not conducted simultaneously. Dosages used for AA, indomethacin and NDGA were based on those previously used for bovine luteal cell culture and in vitro fertilization experiments (Alila et al., 1990; Okuda et al., 1995; Baptista et al., 2000).

\section{Embryo evaluation}

Embryo production was assessed by cleavage rate (embryos/inseminated oocytes x 100) at 24 hours after zygote 
transfer to monolayers, day 7 (D7) and day 8 (D8) embryo rates (D7 or D8 embryos / cleaved embryos x 100) and hatched embryo rate (hatched embryos / D8 embryos x 100).

Quality was evaluated on D8 by scoring embryos from grade 1 (very good) to grade 4 (bad) based on Lindner \& Wright (1983) classification. Grades 1, 2 and 3 are considered transferable and grade 4 non-transferable embryos.

Embryo development was studied daily between D7 and D10 by identifying morulae (M), young blastocysts (YB), blastocysts (BL), expanded blastocysts (XB) and hatched blastocysts (HB). This evaluation was performed in order to detect differences in embryo growth rate dynamics among days and treatments.

\section{Statistical analysis}

Results on embryo production, development and quality are expressed in tables and graphics by mean \pm standard error of the mean (s.e.m.) of 11 replicates.

Values calculated from all replicates were compared among groups by $2 \times 2$ Chi Square using Fisher's exact test at least with a 95\% confidence level (Statsoft inc, 1995).

\section{Results}

\section{Experiment 1}

Embryo supplementation with AA from 1-cell to hatching resulted on a significant increase of cleaved embryos $(\mathrm{P}<0.0001)$ and a decrease of hatched embryos $(\mathrm{P}<0.05)$ (Table 1).

Quality rates of D8 transferable (grades 1, 2 and 3) embryos were similar comparing control (47.3\%) and AA1 (49.8\%) groups (Table 2). However, a higher proportion of grade 3 embryos was observed in group AA1 $(\mathrm{P}<0.02)$ (Table 2).
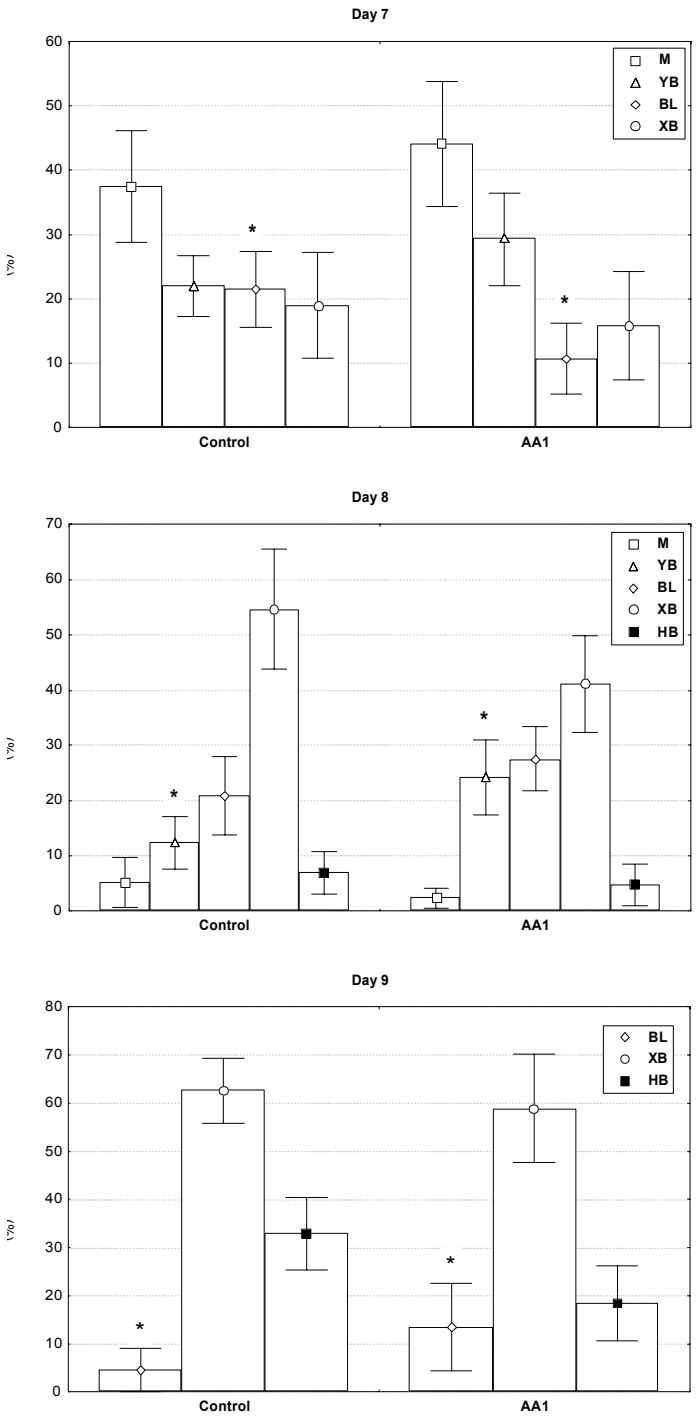

Figure 1 - Arachidonic acid (AA1) effect on bovine embryos growth rate dynamic. Embryo development stages: $M=$ morula, $Y B=y o u n g$ blastocyt, $B L=$ blastocyst, $\mathrm{XB}=$ expanded blastocyst, $\mathrm{HB}=$ hatched blastocyst $(\% \pm$ s.e.m.; $n=11$ replicates; * $P<0.05)$.

Table 1 - Arachidonic acid (AA1) effect on in vitro produced bovine embryos (11 replicates)

\begin{tabular}{|c|c|c|c|c|c|c|c|c|c|}
\hline \multirow[t]{2}{*}{ Group } & \multirow{2}{*}{$\begin{array}{c}\text { IVF oocytes } \\
n\end{array}$} & \multicolumn{2}{|c|}{ Cleavage } & \multicolumn{2}{|c|}{ D7 embryos } & \multicolumn{2}{|c|}{ D8 embryos } & \multicolumn{2}{|c|}{ Hatched embryos } \\
\hline & & $\mathrm{n}$ & $\% \pm$ s.e.m. & $\mathrm{n}$ & $\% \pm$ s.e.m. & $\mathrm{n}$ & $\% \pm$ s.e.m. & $\mathrm{n}$ & $\% \pm$ s.e.m. \\
\hline Control & 715 & 542 & $76.3 \pm 2.1^{\mathrm{a}}$ & 96 & $19.3 \pm 2.6$ & 96 & $19.2 \pm 2.7$ & 64 & $62.4 \pm 8.0^{\mathrm{a}}$ \\
\hline AA 1 & 730 & 628 & $86.7 \pm 1.7^{b}$ & 129 & $20.9 \pm 3.0$ & 109 & $18.7 \pm 3.2$ & 58 & $42.0 \pm 10.5^{b}$ \\
\hline
\end{tabular}

Data within the same columns with different superscripts are statistically different $(\mathrm{P}<0.05)$.

Table 2 - Effect of arachidonic acid (AA1) supplementation on quality of in vitro produced bovine embryos (grade $1=$ =very good .... grade $4=$ bad, 11 replicates)

\begin{tabular}{lcrrr}
\hline Group & $\mathrm{n}$ & \multicolumn{2}{c}{ Day 8 embryo quality $(\% \pm$ s.e.m) } \\
\cline { 3 - 5 } & & Grade 1 & Grade 2 & Grade 3 \\
\hline Control & 96 & $6.9 \pm 3.8$ & $21.1 \pm 6.2$ & $19.3 \pm 5.2^{\mathrm{a}}$ \\
A A 1 & 109 & $5.3 \pm 3.9$ & $16.2 \pm 4.9$ & $52.7 \pm 10.5$ \\
\hline
\end{tabular}

Data within the same columns with different superscripts are statistically different $(\mathrm{P}<0.05)$. 
Supplementation with AA1 induced a delay on embryo development on days 7-9 (Figure 1). At D7, AA1 induced a significant decrease on BL production rate (10.7 vs. $21.5 \%$; $\mathrm{P}<0.008)$. Similarly, AA1 reduced YB production rate on $\mathrm{D} 8$ (24.3 vs. $12.4 \% ; \mathrm{P}<0.05$ ) and that of $\mathrm{BL}$ on $\mathrm{D} 9$ ( 13.5 vs. $4.6 \%$; $\mathrm{P}<0.05$ ) compared to the control. No significant differences were observed on D10. Results above clearly showed a delay on embryonic development in group AA1 from D7 to D9.

\section{Experiment 2}

As observed in experiment 1, supplementation with AA2 resulted on a significant increase $(\mathrm{P}<0.003)$ of cleaved embryos (Table 3). However, supplementation with AA2 restricted to the first three days did not affect the later embryo development (Table 3). While INDO was an intermediate between control and AA2 groups for number of cleaved embryos, NDGA reduced significantly not only the number $(\mathrm{P}<0.04)$ but also $\mathrm{D} 7$ embryo production $(\mathrm{P}<0.03$, Table 3).

Day 8 embryo quality was negatively affected only by NDGA resulting in less grade $2(\mathrm{P}<0.05)$ and more grade 4 $(\mathrm{P}<0.004)$ embryos compared to the remaining treatments (Table 4).

As opposed to AA administered during all co-culture period in experiment 1 , supplementation restricted to the first three days did not induce a delay in embryonic growth rate $(\mathrm{P}>0.05)$.

Arachidonic acid stimulated embryo development prior to genomic activation as shown in both experiments. This is the first report of such an early AA interference on embryo development because in previous studies were investigated embryos beyond 8-16 cell stage (Lim \& Hansel, 1996 and 2000).

Genomic activation in bovine occurs at $8-16$ cells (Barnes \& Eyestone, 1990) approximately 72 hours after fertilization. Results showed that AA increased cleavage and according to Lim \& Hansel (1996 and 2000) it seems to have a longacting effect until the morula stage avoiding the developmental block.

The results support the hypothesis of the beneficial role of AA during early embryo development stages on normal functioning of COX and LOX pathways. COX inhibition only prevented the beneficial role of AA to be expressed while LOX inhibition by NDGA reduced embryo cleavage rate. Previous studies showed that COX metabolites such as PGE2 (Pereira et al., 2001) and PGI2 (unpublished results) significantly increased cleavage rate emphasising the role COX pathway on embryo development. We are not aware of similar studies regarding LOX metabolites. However, our results indicated a physiological role of these metabolites during the first cleavages in embryo development, although a direct toxic effect of NDGA on embryo cells can not be excluded.

Arachidonic acid delayed embryo development beyond D7 and reduced hatched embryo rate. We could prevent this deleterious effect by avoiding supplementation after day 3 . Blastocyst formation was not observed in any treatment in

Table 3 - Effect of arachidonic acid (AA2), AA2 with indomethacin (INDO) or AA2 with nordihydroguaiaretic acid (NDGA) added to medium culture (first 3 days) on subsequent in vitro bovine embryo development (11 replicates)

\begin{tabular}{|c|c|c|c|c|c|c|c|c|c|}
\hline \multirow[t]{2}{*}{ Group } & \multirow{2}{*}{$\begin{array}{c}\text { IVF oocytes } \\
n\end{array}$} & \multicolumn{2}{|c|}{ Cleavage } & \multicolumn{2}{|c|}{ D7 embryos } & \multicolumn{2}{|c|}{ D8 embryos } & \multicolumn{2}{|c|}{ Hatched embryos } \\
\hline & & $\mathrm{n}$ & $\% \pm$ s.e.m. & $\mathrm{n}$ & $\% \pm$ s.e.m. & $\mathrm{n}$ & $\% \pm$ s.e.m. & $\mathrm{n}$ & $\% \pm$ s.e.m. \\
\hline Control & 646 & 337 & $51.8 \pm 3.0^{\mathrm{a}}$ & 84 & $23.3 \pm 3.4^{\mathrm{a}}$ & 82 & $22.5 \pm 3.5$ & 53 & $60.7 \pm 8.1$ \\
\hline A A 2 & 642 & 388 & $58.3 \pm 2.9^{b}$ & 99 & $24.4 \pm 3.0^{\mathrm{a}}$ & 97 & $24.2 \pm 2.9$ & 65 & $55.3 \pm 11.3$ \\
\hline INDO & 658 & 364 & $54.8 \pm 3.4^{\mathrm{ab}}$ & 91 & $21.7 \pm 4.2^{\mathrm{a}}$ & 89 & $21.4 \pm 4.0$ & 58 & $53.9 \pm 8.8$ \\
\hline NDGA & 648 & 300 & $46.7 \pm 4.9^{\mathrm{c}}$ & 54 & $13.9 \pm 3.5^{b}$ & 57 & $14.6 \pm 3.5$ & 33 & $26.8 \pm 9.9$ \\
\hline
\end{tabular}

Data within the same columns with different superscripts are statistically different $(P<0.05)$.

Table 4 - Effect of arachidonic acid (AA2), AA2 with indomethacin (INDO) or AA2 with nordihydroguaiaretic acid (NDGA) added to culture medium (first 3 days) on day 8 bovine embryo quality (grade 1=very good .... grade 4=bad, 11 trials)

\begin{tabular}{lllccc}
\hline Group & $\mathrm{n}$ & \multicolumn{5}{c}{ Day 8 embryo quality $(\% \pm$ s.e.m) } \\
\cline { 3 - 6 } & & Grade 1 & Grade 2 & Grade 3 & Grade 4 \\
\hline Control & 82 & $2.2 \pm 1.2$ & $16.9 \pm 5.3^{\mathrm{a}}$ & $38.9 \pm 6.3$ & $33.0 \pm 7.7^{\mathrm{a}}$ \\
AA2 & 97 & $3.4 \pm 2.1$ & $15.9 \pm 6.1^{\mathrm{a}}$ & $44.1 \pm 10.2$ & $36.6 \pm 11.2^{\mathrm{a}}$ \\
INDO & 89 & $4.3 \pm 3.1$ & $11.9 \pm 3.8^{\mathrm{a}}$ & $40.3 \pm 7.4$ & $43.4 \pm 7.9^{\mathrm{a}}$ \\
NDGA & 57 & $0.5 \pm 0.5$ & $2.6 \pm 1.8^{\mathrm{b}}$ & $14.0 \pm 6.1$ & $64.7 \pm 11.9^{\mathrm{b}}$ \\
\hline
\end{tabular}

Data within the same columns with different superscripts are statistically different $(\mathrm{P}<0.05)$. 
a basic defined bovine embryo culture medium (BECM) supplemented with AA. The detrimental effect of AA observed in the BECM system on embryo development was overcome by glutathione (GSH) showing the importance of the antioxidative role of GSH at this stage (Lim \& Hansel, 1996).

All the effects observed on embryos emerging from the challenge with AA and COX/LOX inhibitors may arise from metabolic processes within the embryo itself or from granulosa cells used in our system. Granulosa cells supplemented with AA are known to synthesize PGE1, PGE2 and PGI2 as well as 5-12- and 15-HETE (Feldman et al., 1986). Bovine embryos are able to metabolize AA into prostaglandins (Lewis et al., 1982; Gurevich \& Shemesh, 1994; Nadeau et al., 1994) but LOX metabolites have not been identified prior to hatching stage. Moreover, the mechanism through which AA exerted its effects, besides COX and LOX metabolites, could be through a direct action as an intracellular second messenger or by interacting with other AA metabolic pathways (O’Neill et al., 1990; Piomelli, 1996).

\section{Conclusions}

Arachidonic acid has a two-phase action on bovine embryos, improving early embryo development and impairing embryo growth from D7 onwards and hatching rates. Both COX and LOX were found to be important pathways to promote cleavage. Arachidonic acid and its cascade metabolites positively affected embryo development when AA was available until three days of in vitro culture.

\section{Literature Cited}

ALILA, H.W.; CORRADINO, R.A.; HANSEL, W. Arachidonic acid and its metabolites increase cytosolic free calcium in bovine luteal cells. Prostaglandins, v.39, p.481-496, 1990.

BAPTISTA M.C.; MARQUES, C.C.; PEREIRA, R.M. et al. Effect of prostaglandins on bovine sperm capacitation and fertilization in vitro. Theriogenology, v. 53, p.416, 2000.

BARNES, F.L.; EYESTONE, W.H. Early cleavage and the maternal zygotic transition in bovine embryos. Theriogenology, v.33, p.141-152, 1990.

BIGGERS, J.D.; LEONOV, B.V.; BASKAR, J.F. et al. Inhibition of hatching of mouse blastocysts in vitro by prostaglandin antagonists. Biology of Reproduction, v.19, p.519-533, 1978.

CHARPIGNY, G.; REINAUD, P.; TAMBY, J.P. et al. Cyclooxygenase-2 unlike cyclooxygenase- 1 is highly expressed in ovine embryos during the implantation period. Biology of Reproduction, v.57, p.1032-1040, 1997.

FELDMAN, E.; HABERMAN, S.; ABISOGUN, A.O. et al. Arachidonic acid metabolism in human granulosa cells: evidence for cyclooxygenase and lipoxygenase activity in vitro. Human Reproduction, v.1, p.353-356, 1986.

GORDON, I. Laboratory production of cattle embryos. Wallingford: Cab International, 1994. 640p.

GUREVICH, M.; HAREL-MARKOWITZ, E.; MARCUS, S. et al. Prostaglandin production by the oocyte cumulus complex around the time of fertilization and the effect of prostaglandin $\mathrm{E}$ on the development of early bovine embryo. Reproduction Fertility and Development, v.5, p.281-283, 1993.

GUREVICH, M.; SHEMESH, M. Induction of cyclooxygenase and prostaglandin E2 production by the bovine pre-embryos. Reproduction Fertility and Development, v.6, p.687-691, 1994.

LEWIS, G.S. Indomethacin inhibits the uptake of 22 sodium by ovine trophoblastic tissue in vitro. Prostaglandins, v.31, p.111-122, 1986.

LEWIS, G.S. Prostaglandin secretion by the blastocyst. Journal of Reproduction and Fertility, v.37, p.261-267, 1989 (suppl.).

LEWIS, G.S.; THACTHER, W.W.; BAZER, F.W. et al. Metabolism of arachidonic acid in vitro by bovine blastocyst and endometrium. Biology of Reproduction, v.27, p.431-439, 1982.

LIM, J.M.; HANSEL, W. Roles of growth factors in the development of bovine embryos fertilized in vitro and cultured singly in a defined medium. Reproduction Fertility and Development, v.8, p.1199-1205, 1996.

LIM, J.M.; HANSEL, W. Exogenous substances affecting development of in vitro-derived bovine embryos before and after embryonic genome activation. Theriogenology, v.53, p.1081-1091, 2000.

LINDNER, G.M.; WRIGHT, R.W. Bovine embryo morphology and evaluation. Theriogenology, v.20, p.407-416, 1983.

MARQUES, C.M.; PEREIRA, R.M.; VASQUES, M.I. et al. Role of prostaglandins on bovine oocyte maturation in vitro. In: IBERIAN CONGRESS ON ANIMAL REPRODUCTION, 1., 1997, Estoril. Proceedings... Estoril: Portuguese Animal Reproduction Society, 1997. v.2, p.142-149.

MURDOCH, W. Disruption of cellular associations within the granulosal compartment of periovulatory ovine follicles: relationship to maturation of the oocyte and regulation by prostaglandins. Cell Tissue Research, v.252, p.459-462, 1988.

NADEAU, Y.; SIRARD, M.A.; LACOULINE, L. et al. Prostaglandins production as indicator of bovine embryo quality at early blastocyst stage. Theriogenology, v.41, p.263, 1994.

O'NEILL, C.; WELLS, X.; BATTYE, K. Embryo-derived platelet activating factor: interactions with the arachidonic acid cascade and the establishment and maintenance of pregnancy. Reproduction Fertility and Development, v.2, p.423-441, 1990.

OKUDA, K.; UENOYAMA, Y.; MIYAMOTO, A. et al. Effects of prostaglandins and oestradiol-17 $\beta$ on oxytocin binding in cultured bovine luteal cells. Reproduction Fertility and Development, v.7, p.1045-1051, 1995.

ORCZYK, G.P.; BEHRMAN, H.R. Ovulation blockade by aspirin or indomethacin - in vivo evidence for a role of prostaglandin in gonadotrophin secretion. Prostaglandins, v.1, p.3-20, 1972.

PEREIRA, R.M.; MARQUES, C.C.; BAPTISTA, M.C. et al. Effect of PGE2 and prostaglandin synthesis inhibition on bovine in vitro embryo development. In: IBERIAN CONGRESS ON ANIMAL RePRODUCTION, 2001, Porto. Proceedings... Porto: Portuguese Animal Reproduction Society, 2001. p.375-380.

PIOMELLI, D. Arachidonic acid in cell signalling. Austin: R.G. Lands Company and Chapman \& Hall. 1996. 199p.

REICH, R.; KOHEN, F.; NAOR, Z. et al. Possible involvement of lipoxygenase products of arachidonic acid in ovulation. Prostaglandins, v.26, p.1011-1020, 1983.

ROBERTSON, R.P. Molecular regulation of prostaglandin synthesis. Implications for endocrine systems. Trends in Endocrinology and Metabolism, v.6, p.293-297, 1995.

SALARI, H.; BRAQUET, P.; BORGEAT, P. Comparative effects of indomethacin, acetylenic acids, 15-HETE, nordihydroguaiaretic acid and $\mathrm{BW}$ on the metabolism of arachidonic acid in human leukocytes and platelets. Prostaglandins Leukotrienes Medicine, v.13, p.53-59, 1984. 
SAMUELSSON, B.; BORGEAT, P.; HAMMAESTROM, S. et al. Introduction of a nomenclature: leukotrienes. Prostaglandins, v.17: p.785-787, 1979.

STATSOFT INC. STATISTICA for Windows [Computer program manual]. Tulsa, OK, 1995.

THATCHER, W.W.; WOLFENSON, D.; CURL, J.S. et al. Prostaglandin dynamics associated with development of the bovine conceptus. Animal Reproduction Science, v.7, p.149$176,1984$.
Van der WEIDEN, R.M.; WISSE, L.J.; HELMERHORST, F.M. et al. Immunohistochemical and ultrastructural localization of prostaglandin $\mathrm{H}$ synthase in the preimplantation mouse embryo. Journal of Reproduction and Fertility, v.107, p.161-166, 1996.

Recebido: $04 / 04 / 05$ Aprovado: 19/08/05 